\title{
An approach towards measurement of sexual behavior in Cholistani service bulls and its association with serum testosterone levels
}

\author{
Umer Farooq ${ }^{1}$, Waseem Abbas $^{2}$, Umair Riaz ${ }^{1}$, Musadiq Idris ${ }^{1}$, Sajid \\ Hameed $^{1}$, Mushtaq Hussain Lashari ${ }^{3 *}$ and Muhammad Khalid ${ }^{2}$ \\ 1. University College of Veterinary and Animal Sciences, The Islamia University of Bahawalpur-Pakistan \\ 2. Livestock \& Dairy Development Department, Punjab-Pakistan \\ 3. Department of Zoology, The Islamia University of Bahawalpur-Pakistan \\ *Corresponding author's email: mushtaqlashary@gmail.com \\ Citation \\ Umer Farooq, Waseem Abbas, Umair Riaz, Musadiq Idris, Sajid Hameed, Mushtaq Hussain Lashari and \\ Muhammad Khalid. An approach towards measurement of sexual behavior in Cholistani service bulls and its \\ association with serum testosterone levels. Pure and Applied Biology. Vol. 9, Issue 1, pp369-375.
} http://dx.doi.org/10.19045/bspab.2020.90041

\begin{tabular}{llll}
\hline \hline Received: 24/08/2019 & Revised: 25/10/2019 & Accepted: 01/11/2019 & Online First: 06/11/2019 \\
\hline
\end{tabular}

\section{Abstract}

The present work was conducted with an aim to analyze various sexual behavior attributes for Cholistani service bulls $(n=10)$ being reared for AI at Semen Production Unit, Karaniwala, Bahawalpur, Pakistan and their relationship with serum testosterone levels. Bulls were divided into two equal groups $(n=5$ per group) viz. young (2-3 years of age) and adult (4-8 years of age). The exposure tests for assessment of sexual behavior and scoring were performed during semen collection. A total of 40 blood samples, (04 samples per animal; were 20 samples per group) were aseptically collected and used for assessment of serum testosterone concentration through automated immunoanalyser. Amongst the studied behavioral attributes, 'reaction during approach', 'sexual interest' and 'ejaculate response' were significantly $(\mathrm{P} \leq 0.05)$ higher in adults as compared to their young counterparts. Adults had a significantly $(\mathrm{P} \leq 0.05)$ higher testosterone concentration $(6.59 \pm 0.3 \mathrm{ng} / \mathrm{mL})$ as compared to their young counterparts $(5.34 \pm$ $0.3 \mathrm{ng} / \mathrm{mL}$ ). A positive correlation between serum testosterone concentration and sexual behavior score was noticed both for young and adult bulls, though statistically non-significant $(\mathrm{P} \geq 0.05)$. It is concluded that there is a significant difference in sexual behavior attributes and serum testosterone levels of young and adult Cholistani service bulls. This is a first attempt to analyze sexual behavioral attributes of young and adult Cholistani breeding bulls. A time-lined study need to be devised for this breed in future in order to ascertain age of puberty and allied endocrine patterns.

Keywords: Cholistani bulls; Serum testosterone profile; Sexual behavior

\section{Introduction}

Testosterone, released from the Leydig cells of the testis, acts both at central and peripheral levels, and is pivotal for various functions such as optimal spermatogenesis, development/maintenance of libido, increased muscle mass, secretory activity of accessory glands, sexual behavior, and secondary sexual characteristics in males [1-3]. Extensive studies have elaborated that it has a positive correlation with various attributes viz. body weight, scrotal 
circumference, testicular measurements, seminal attributes, sexual behavior and fertility both in Bos indicus and Bos Taurus breeding bulls [2-5] has been well established that the bulls of Zebu breed have lower serum testosterone levels as compared to their in Bos taurus counterparts $[1,6]$.This, ultimately results in a decreased sexual activity in zebu.

Selection of bulls for their breeding capability is attained through an extensive Breeding Soundness Evaluation (BSE) which encompasses various physical parameters of the animal along with its seminal attributes. Yet, ironically, sexual behavior is not taken into detailed account while conducting these BSEs. Sexual behavior of breeding bulls if correlated with serum testosterone level and various seminal attributes can predict a fairly reliable tool for economic boost through enhanced fertility. Scanty studies on sexual behavior and libido scoring of Sahiwal breeding bulls have already been reported $[4,5,7]$.

The Cholistani cattle is an indigenous humped zebu breed of Pakistan which has lately attained avid attention. Extensive work related to its productive, reproductive and hematochemical traits has been reported by our group since the dawn of 2010 [2, 3, 8-12] Our past work has also highlighted its phenotypic characteristics and patterns of its rearing at the Cholistan desert, Pakistan by the nomadic pastoralists [13]. Resultantly, this formerly neglected breed has now been introduced both at national and international level equally. The sexual behavior patterns, however, have not yet been elucidated for the bulls of this breed. This research work is a continuation of our work on this breed being conducted with an aim to analyze various sexual behavior attributes for young and adult Cholistani breeding bulls being harbored for artificial insemination and their relationship with serum testosterone levels.

\section{Materials and methods Study area}

This research work was executed at the Semen Production Unit (SPU), Karaniwala, Bahawalpur, which is situated in the Cholistan Desert of Pakistan. This desert is spread over an area of $26,000 \mathrm{Km}^{2}$ at latitudes $27^{\circ} 42^{\prime}$ and $29^{\circ} 45^{\prime}$ North and longitudes $69^{\circ} 52^{\prime}$ and $75^{\circ} 24^{\prime}$ East and at an altitude of about $112 \mathrm{~m}$ above the sea level 13 The detailed climatology has been given in detail elsewhere $[10,12]$.

\section{Experimental bulls}

The present work included Cholistani service bulls ( $n=10)$ which were clinically sound and showed no signs of any disease. They were divided into two equal groups ( $n$ $=5$ per group) viz. young (2-3 years of age) and adult (5-8 years of age) with five animals in each group. They were housed individually in a $10 \times 12 \mathrm{~m}$ separate pens with a $4 \times 4 \mathrm{~m}$ shelter at the center. At the time of the research, adult bulls were donating semen of acceptable quality for AI whereas the young ones were candidate bulls under training. They were being fed with good quality seasonal fodder at the rate of $10 \%$ of their body weight, with two to three $\mathrm{kg}$ of concentrate (Anmol wanda ${ }^{\circledR}$ ) [10] per bull per day. Water was freely accessible to them. The animals were vaccinated against Hemorrhagic Septicemia and Foot and Mouth Disease and screening against venereal diseases was carried out as per stipulated routine. Endoand ecto-parasites were controlled through preventive controls, normally twice in a year, or upon need [10].

\section{Assessment of sexual behavior}

The sexual behavior studies were carried out at the time of semen collection/training and various sexual behavior attributes were observed/ noted with the help of a scorecard [14]. All sexual behavior observations were recorded by a single observer. Four observations were made for each animal. The sum of score for four observations and scoring pattern is given in (Table 1). 


\section{Blood collection and serum testosterone concentration}

For the purpose of sampling, animals were restrained in the cattle crush by trained personnel and weekly blood collection was carried out a day before semen collection, aseptically from the coccygeal vein. A total of 40 blood samples, with 04 samples per animal were collected (20 samples per group). The same technique and timing of blood collection (04:00pm), day of collection, and same personnel were assigned for sampling in order to minimize the stress to the animal. Blood was stored in vacutainers containing thixiotropic gel separator for serum separation. Samples were brought to the Physiology laboratory of University College of Veterinary \& Animal Sciences, the Islamia University of Bahawalpur and centrifuged for harvesting serum.

MiniVIDAS 12 Compact Automated Immunoanalyzer was utilized for deducing serum testosterone levels. The values of 4.7 and $5.7 \%$ were noticed for inter-assay and intra-assay coefficient of variance respectively and concentration was given in $\mathrm{ng} / \mathrm{mL}$.

\section{Statistical analyses}

Statistical Package for Social Science (SPSS for Windows version 12, SPSS Inc., Chicago, IL, USA) was used for all statistical analyses. The difference between sexual behavior scores and testosterone levels in two groups was determined through unpaired t-test. Pearson's correlation coefficient was implied to attain the relationship between testosterone levels and various behavioral indices of both groups.

\section{Results \\ Sexual behavior}

The results of scoring for sexual behavior attributes in young and adult Cholistani service bulls are presented in (Table 1). Amongst the studied attributes, 'reaction during approach', 'sexual interest' and 'ejaculate response' were significantly $(P \leq$ 0.05 ) higher in adults as compared to their young counterparts; whereas, 'mounting attempts' and 'penile protrusion' showed difference of marginal significance at $P=$ 0.052 and $P=0.051$, respectively. Regarding 'reaction during approach', the young bulls were found to be shy, lethargic and non-aggressive as compared to their adult counterparts. Smelling and intermittent urination were the only two parameters of 'sexual interest' in which the young bulls had a higher score. However, they attained a substantially higher score in mounting attempts being seven (07) as compared to four (04) for adult bulls. Scores for 'penile protrusion' and 'ejaculate response' were substantially lower in young bulls as compared to adults.

\section{Serum testosterone concentrations}

Mean \pm SE values for serum testosterone concentrations for young and adult Cholistani bulls are given in (Table 2). Adults had a significantly $(P \leq 0.05)$ higher testosterone concentration (6.59 \pm $0.3 \mathrm{ng} / \mathrm{mL}$ ) as compared to their younger counterparts $(5.34 \pm 0.3 \mathrm{ng} / \mathrm{mL})$.

\section{The relationships}

The result of correlation analysis revealed positive correlation between serum testosterone concentration and sexual behavior score both for young and adult bulls, though statistically non-significant $(P$ $\geq 0.05$ ) (Table 3). Amongst sexual behavior attributes, 'sexual interest' had highest level of correlation both for young ( $\mathrm{r}=$ $0.814)$ and adult bulls $(\mathrm{r}=0.966)$. 
Table 1. Scoring for evaluation of sexual behavior in Cholistani service bulls

\begin{tabular}{|c|c|c|c|c|}
\hline \multicolumn{4}{|c|}{ Total Score Attained $^{\mathbf{1}}$} & \multirow{2}{*}{$P$-value } \\
\hline Behavior Component & Score & Young $(\mathrm{n}=05)$ & Adult $(\mathrm{n}=05)$ & \\
\hline \multicolumn{5}{|l|}{ Reaction During Approach } \\
\hline Shy & 0 & 0 & 0 & \multirow{4}{*}{$0.01 *$} \\
\hline Slow & 1 & 7 & 3 & \\
\hline Active & 2 & 0 & 22 & \\
\hline Aggressive & 3 & 0 & 28 & \\
\hline \multicolumn{5}{|l|}{ Sexual Interest } \\
\hline Smelling & 1 & 8 & 7 & \multirow{8}{*}{$0.035^{*}$} \\
\hline Licking & 1 & 5 & 9 & \\
\hline Sniffing & 1 & 3 & 9 & \\
\hline Flehmen & 1 & 0 & 9 & \\
\hline Intermittent Urination & 2 & 10 & 8 & \\
\hline Tucking up of Sheath & 2 & 12 & 28 & \\
\hline Chin Rest & 3 & 0 & 9 & \\
\hline Bunting & 3 & 0 & 15 & \\
\hline \multicolumn{5}{|l|}{ Mounting Attempts } \\
\hline Refusal to Mount & 0 & 0 & 0 & \multirow{3}{*}{0.052} \\
\hline Attempt to Mount & 1 & 7 & 4 & \\
\hline Mounting & 2 & 0 & 30 & \\
\hline \multicolumn{5}{|l|}{ Penile Protrusion } \\
\hline Absent & 0 & 0 & 0 & \multirow{4}{*}{0.051} \\
\hline Penile Movement inside Sheath & 1 & 5 & 5 & \\
\hline Partial & 2 & 0 & 14 & \\
\hline Complete & 3 & 0 & 27 & \\
\hline \multicolumn{5}{|l|}{ Ejaculate Response } \\
\hline Absent & 0 & 0 & 0 & \multirow{5}{*}{$0.002 *$} \\
\hline Weak and Slow & 1 & 0 & 2 & \\
\hline Intermediate & 2 & 0 & 18 & \\
\hline Strong and Rapid & 3 & 0 & 27 & \\
\hline Ejaculation & 4 & 0 & 80 & \\
\hline
\end{tabular}

${ }^{1}$ Sum of score for four observations $\times 5$

$* P \leq 0.05$

Table 2. Mean \pm SE values for testosterone concentration in Cholistani service bulls

\begin{tabular}{|c|c|c|c|c|c|c|c|}
\hline & Bull ID & Tes & ne $C$ & atio & nL) & $\begin{array}{c}\text { Overall } \\
\text { Mean }\end{array}$ & $P$-value \\
\hline \multirow{5}{*}{$\begin{array}{l}\text { Young } \\
(\mathrm{n}=05)\end{array}$} & KWC-75 & 6.2 & 5.4 & 2.8 & 5.1 & \multirow{5}{*}{$5.34 \pm 0.3$} & \multirow{10}{*}{$0.014 *$} \\
\hline & KWC-76 & 5.4 & 3.2 & 4.9 & 4.2 & & \\
\hline & KWC-77 & 7.2 & 4.8 & 7.0 & 6.8 & & \\
\hline & KWC-78 & 6.0 & 8.0 & 5.2 & 7.0 & & \\
\hline & KWC-79 & 4.3 & 4.0 & 4.1 & 5.2 & & \\
\hline \multirow{5}{*}{$\begin{array}{c}\text { Adult } \\
(\mathrm{n}=05)\end{array}$} & KWC-45 & 7.9 & 6.2 & 7.7 & 7.0 & \multirow{5}{*}{$6.59 \pm 0.3$} & \\
\hline & KWC-46 & 7.0 & 3.5 & 7.0 & 6.5 & & \\
\hline & KWC-47 & 9.0 & 9.0 & 6.2 & 5.2 & & \\
\hline & KWC-48 & 5.2 & 5.6 & 9.0 & 7.1 & & \\
\hline & KWC-49 & 6.1 & 8.2 & 3.2 & 5.2 & & \\
\hline
\end{tabular}


Table 3. Pearson's correlation coefficient of serum testosterone level with behavioral parameters in Cholistani service bulls

\begin{tabular}{|c|c|c|}
\hline Groups & Parameters & R value \\
\hline \multirow{4}{*}{$\begin{array}{c}\text { Young } \\
(\mathrm{n}=5)\end{array}$} & Reaction during approach & 0.287 \\
\cline { 2 - 3 } & Sexual interest by test animals & 0.814 \\
\cline { 2 - 3 } & Mounting Attempts & 0.374 \\
\cline { 2 - 3 } & Penile Protrusion & 0.287 \\
\cline { 2 - 3 } & Ejaculate response & - \\
\cline { 2 - 3 } $\begin{array}{c}\text { Adult } \\
(\mathrm{n}=5)\end{array}$ & Reaction during approach & 0.686 \\
\cline { 2 - 3 } & Sexual interest by test animals & 0.966 \\
\cline { 2 - 3 } & Mounting Attempts & 0.375 \\
\cline { 2 - 3 } & Penile Protrusion & 0.418 \\
\hline
\end{tabular}

\section{Discussion}

Reproductive efficiency of breeding bulls is a vital factor in determining optimal fertility and hence, appropriate herd profitability. The BSEs are implied to assess baseline criteria for determining bull's appropriateness as a breeder. These evaluations include assessment of semen quality parameters, ejaculate properties and basic physical soundness. However, these BSEs do not incorporate sexual behavior [15]. The present study is the first of its kind being reported for Cholistani service bulls (an indigenous humped zebu breed of Pakistan) with an objective to assess their various sexual behavior attributes and to correlate them with serum testosterone levels.

Regarding sexual behavior attributes, smelling and intermittent urination were the only two parameters of 'sexual interest' in which the young bulls had a higher score in present study. However, they attained a substantially higher score in mounting attempts being seven (07) as compared to four (04) for adult bulls. Literature review does not reveal past work done on similar patterns/attributes of sexual behavior in zebu bulls studied in the present study. Though, certain other behavioral attributes viz libido score [2], reaction time, sexual behavior score, erection score and dismounting time [7] have been studied for Sahiwal bulls. Similarly, various factors affecting these attributes have also been navigated such as effect of semen collection floor [7] multiple versus single sire groups and various female stimuli [15] In general, the results of present study are in line with those of Singh [5] and Elrabie [7] who while working on Sahiwal bulls concluded that the bulls of Bos indicus are generally sexually sluggish and do not attain ability to donate semen till beyond three years of age. A genetic predisposition or a lower serum testosterone level, as discussed ahead, could be a plausible justification.

In the present study, adults had a significantly higher testosterone concentration as compared to their younger counterparts. The results are in accordance to previous studies conducted on Sahiwal breeding bulls in Pakistan which have reported significant effect of age and season on libido score and serum testosterone level $[1,4,16]$. Previous studies have also revealed an exponential increase in serum testosterone level of growing Sahiwal bulls [17] similar to the results of present study. It has been elaborated earlier that the serum testosterone levels in zebu bulls is normally lesser as compared to exotic (B. taurus) bulls $[1,2]$. This ultimately, results in a decreased sexual activity in zebu bulls as can be witnessed in results of sexual behavior attributes of present study.

A mean serum testosterone value of $6.59 \pm 0.3 \mathrm{ng} / \mathrm{mL}$ for adult Cholistani bulls in present study is in line with work by Mahmood [2] who revealed a $5.81 \pm 0.32 \mathrm{ng} / \mathrm{mL}$ for bulls of similar breed. Higher values of $8.6 \pm 0.7 \mathrm{ng} / \mathrm{mL}$ and $10.0 \pm 0.43 \mathrm{ng} / \mathrm{mL}$ have been reported for Nigerian indigenous Zebu Bunaji bulls and 
Pakistani Sahiwal bulls, respectively $[1,6]$. A wide range was noticed in testosterone levels in our study (from 3.2 to $9.0 \mathrm{ng} / \mathrm{mL}$ ) which is in line with work of [6]. This wide range has been attributed to photoperiodicity, climatic conditions and variations in posture $[2,6]$.

Role of testosterone, released from the Leydig cells of testes, has been defined in detail earlier. It achieves both endocrine and paracrine distribution resulting in primary and secondary male sex characters $[18,19]$. Optimal spermatogenesis, libido and sexual activity, and secretory accessory glands are few of its functions. A lower serum testosterone level both for young and adult bulls in present study as compared to other indigenous zebu breeds as discussed above may be a plausible justification for lower sexual activity in Cholistani bulls.

The result of correlation analysis revealed positive correlation between serum testosterone concentration and sexual behavior score both for young and adult bulls. Amongst sexual behavior attributes, 'sexual interest' had highest level of correlation both for young and adult bulls. These results are in accordance with previous work conducted on bulls of same breed which reported statistically positive $(P \leq 0.01)$ correlation of libido indices (reaction time, libido index, time elapsed between two ejaculates) with serum testosterone levels [2]. A statistically nonsignificant correlation in the present study could be attributed to comparatively lower testosterone levels in this breed as compared to other indigenous zebu breeds.

\section{Conclusion}

Based on the results described in the present study, it is concluded that there is a significant difference in sexual behavior attributes and serum testosterone levels of young and adult Cholistani service bulls. Furthermore, young bulls do not acquire the ability to donate semen till beyond three years of age. We recommend the sexual behavior attributes to be incorporated in BSEs for selection of breeding/candidate bulls. This preliminary investigation opens broader avenues of detailed research on endocrine physiology of Cholistani service bulls with higher number of samples and enhanced sexual ethograms. A time-lined study need to be devised for this breed in future in order to ascertain age of puberty and allied endocrine patterns. A correlation study of these sexual behavioral attributes with seminal attributes and fertility can also be beneficial.

\section{Authors' contributions}

Conceived and designed the experiments: U Farooq, S Hamid \& M Idris, Performed the experiments: U Riaz \& M Khalid, Analyzed the data: W Abbas, U Riaz \& MH Lashari, Contributed materials/ analysis/ tools: M Khalid, Wrote the paper: U Farooq $\&$ MH Lashari.

\section{References}

1. Gulia S, Sarkar M, Kumar V, Meyer HHD \& Prakash BS (2010). Divergent development of testosterone secretion in male zebu (Bos indicus) and crossbred cattle (Bos indicus x Bos taurus) and buffaloes (Bubalus bubalis) during growth. Trop Anim Health Prod 42: 1143-1148.

2. Mahmood SA, Ijaz A, Ahmad N, Rehman H, Zaneb H \& Farooq U (2013). Studies on libido and serum testosterone concentration of Cholistani AI bulls under stress free and stressful seasons. J Anim Plant Sci 23: 1491-1495.

3. Mahmood SA, Ijaz A, Ahmad N, Rehman H, Zaneb $\mathrm{H}$ \& Farooq U (2014). A study on relationships among age, body weight, orchidometry and semen quality parameters in adult Cholistani breeding bulls. J Anim Plant Sci 24: 380-384.

4. Ahmad M, Asmat MT \& Rehman NU (2005). Relationship of testicular size and libido to age and season to Sahial bulls. Pak Vet J 25: 67-70.

5. Singh S, Bhakat M, Mohanty TK, Kumar A, Gupta AK, Chakravarty AK \& Singh P (2015). Sexual behavior and its relationship with semen quality 
parameters in Sahiwal breeding bulls. Vet World 8: 745.

6. Sekoni VO, Rekwot PI, Bawa EK \& Barje PP (2008). Effects of age and time of sampling on serum testosterone and spermiogram of Bunaji and $\mathrm{N}$ 'Dama bulls. Res J Vet Sci 1: 50-55.

7. Elrabie KA, Raina VS, Gupta AK \& Mohanty TK (2008). Effect of semen collection floor on sexual behavior and semen quality of Sahiwal bulls. Pak J Agri Sci 45: 201-206.

8. Farooq U, Ijaz A, Ahmed N, Rehman $H$ \& Zaneb H (2012). Haematologic profile revisited: Adult Cholistani breeding bulls as a model. J Anim Plant Sci 22: 835-839.

9. Farooq U, Ijaz A, Ahmad N, Rehman $H$ \& Zaneb H (2013). Seasonal variations in certain physical and biochemical attributes of semen from Cholistani bulls. Pak Vet J 33: 510514.

10. Farooq U, Ijaz A, Ahmad N, Rehman H \& Zaneb H (2013b). Investigations on semen quality and freezability of Cholistani breeding bulls-A preliminary study from Cholistan desert of Pakistan. J Anim Plant Sci 23: 359-363.

11. Farooq U, Mahmood SA, Ahmad I, Ahmad N, Idris M, \& Abbas MT (2015). Evaluation of post thaw sperm parameters and fertility of Cholistani service bulls. Turk J Vet Anim Sci 39: 472-479.
12. Farooq U, Ahmad N, Ahmad I, Mahmood SA, Andrabi SMH \& Idris M (2017). Effect of seasonal variations on hematochemical profile of Cholistani service bulls. J Appl Anim Res 45: 85-89.

13. Farooq U, Samad HA, Sher F, Asim M \& Khan MA (2010). Cholistan and Cholistani breed of cattle. Pak Vet J 30: 126-130.

14. Ahmad N, Shahab M, Anzar M \& Arslan M (1991). Changes in the behaviour and androgen levels during pubertal development of the buffalo bull. Appl Anim Behav Sci 32: 101-105.

15. Bailey JD (2003). An approach to the measurement of sexual behavior in the bull (Bos taurus) using variable female stimulus conditions. PhD Diss, Univ Kentucky USA.

16. Ahmad M, Asmat MT, Rehman NU \& Khan MZ (2003). Semen characteristics of Sahiwal bulls in relation to age and season. Pak Vet J 23: 202-206.

17. Khate K (2005). Studies on multistage selection of dairy bulls, MV Sc Thesis, Natl. Dairy Res.Inst., Haryana, India.

18. Huleihel M \& Lunenfeld E (2004). Regulation of spermatogenesis by paracrine/autocrine testicular factors. Asian J Androl 6: 259-268.

19. Swerdloff RS. \& Wang C (2010). Dihydrotestosterone: Hormone or autocrine-paracrine signal. Ann Intern Med 153: 678-679. 